\title{
Kajian Sifat Fisikokimia Tepung Onggok Industri Besar Dan Industri Kecil
}

\author{
Study Of Physicochemical Properties Of Large Industry And Small \\ Industry
}

\author{
Nanti Musita \\ Balai Riset dan Standardisasi Industri Bandar Lampung \\ Jl by pass Soekarno Hatta KM 1 Rajabasa
}

\begin{abstract}
Abstrak
Onggok merupakan limbah padat dari industri tapioka yang masih mengandung karbohidrat yang cukup tinggi (6368\%). Produknya cukup melimpah dan belum dimanfaatkan secara optimal yang sebenarnya masih dapat dimanfaatkan sebagai substrat untuk pertumbuhan mikroba yang dapat menghasilkan produk lain yang bernilai ekonomis.Makalah ini bertujuan untuk melihat perbedaan karakteriktik onggok dari sumber bahan baku yang berbeda (industri besar dan kecil) dan setelah dihidrolisis dengan asam sulfat. Hasil penelitian menunjukkan bahwa Tepung onggok dari industri besar mengandung kadar air, abu, lemak, protein dan pati lebih rendah, namun lebih tinggi kadar serat kasar dibandingkan tepung onggok industri kecil. Konsentrasi asam sulfat yang optimum untuk menghidrolisis onggok Ittara dan industri besar pada konsentrasi 0,4 M selama 30 menit pada suhu $121^{\circ} \mathrm{C}$, menghasilkan gula reduksi sebesar 3,89 mg/ml (industri kecil) dan 2,47 mg/ml (industri besar).
\end{abstract}

Kata kunci : tepung onggok, fisikokimia, industri kecil, industri besar

Abstract

Onggok is a solid waste from tapioca industry which still contains high enough carbodyrate content (63-68\%). The product is quite abundant and has not been utilized optimally which actually can still be used as substrate for microbial growth that can produce other products that have economic value. This paper aims to examine the diverse characteristic characteristics of different sources of raw materials (large and small industries) and after being hydrolyzed with sulfuric acid. The results showed that the flour onggok from large industries contain lower moisture content, ash, fat, protein and starch, but higher crude fiber content than small industry flour. The optimum concentration of sulfuric acid to hydrolyze the Ittara and large industrial clusters at concentrations of $0.4 M$ for 30 minutes at $121^{\circ} \mathrm{C}$, resulting in reducing sugar of $3.89 \mathrm{mg} / \mathrm{ml}$ (small industry) and $2.47 \mathrm{mg} / \mathrm{ml}$ (large industry).

Keywords : onggok flour, pshycochemistry, small industry, large industry

\section{Pendahuluan}

\section{Latar Belakang}

Limbah yang dikeluarkan oleh industri pengolahan tepung tapioka berupa limbah cair dan limbah padat (sekitar 80\%). Limbah padat industri pengolahan tapioka berasal dari proses pengupasan kulit singkong dan ampas (onggok) yang dihasilkan dari proses pemarutan dan pengepresan singkong. Dalam keadaan kering onggok mengeluarkan bau tidak sedap, apalagi dalam keadaan basah yaitu saat musim hujan. Bau tidak sedap ini muncul akibat terjadinya proses pembusukkan onggok yang sangat cepat sering menimbulkan masalah lingkungan, karenanya berpotensi sebagai polutan di daerah sekitar pabrik.
Onggok merupakan limbah padat dari industri tapioka yang masih mengandung karbohidrat (63-68\%) dan air 20\%. Produknya cukup melimpah dan belum dimanfaatkan secara optimal. Onggok dalam keadaan kering mengandung abu 1,18\%, protein kasar 2,80\%, lemak kasar 0,76\%, serat kasar 4,26\%, bahan ekstrak tanpa nitrogen (BETA-N) 91,00\%, Total digestible nutrient (TDN) 85,99\% (Amalia, 2012). Badan Penelitian dan Pengkajian Teknologi Indonesia menyatakan bahwa kandungan pati pada ampas tapioka sebesar 67,8 \% (Puspitasari, 2009). Komposisi onggok bervariasi tergantung jenis ubi kayu, daerah asal serta cara yang dipergunakan dalam pembuatan tepung tapioka. 
Ketersediaan onggok terus meningkat sejalan dengan meningkatnya produksi tapioka. Hal ini diindikasikan dengan semakin meluasnya areal penanaman dan produksi ubikayu. Jumlah onggok tapioka yang dihasilkan dari industri kecil dengan bahan baku lima kg per hari menghasilkan onggok tapioka sebanyak 3,75 kg. Sedangkan industri menengah dengan bahan baku rata-rata sebanyak 20 kg per hari menghasilkan 15 kg onggok tapioka dan industri besar dengan bahan baku $600 \mathrm{~kg}$ per hari dapat menghasilkan onggok tapioka sebanyak 450 kg (Puspitasari, 2009). Dari data tersebut terlihat bahwa jumlah onggok yang dihasilkan dari industri tepung tapioka sangat besar dan onggok ini merupakan limbah pertanian yang berpotensi untuk dimanfaatkan menjadi produk lain

Dengan memperhatikan komposisi kimia dan ketersediaannya, onggok sebenarnya masih dapat dimanfaatkan sebagai substrat untuk pertumbuhan mikroba yang dapat menghasilkan produk lainseperti asam cuka dan etanol dan yang lainnya yang dapat mengurangi pencemaran lingkungan dan meningkatkan nilai guna serta nilai ekonomis onggok.Proses awal yang dapat diterapkan pada onggok adalah proses hidrolisis menggunakan asam.

Hidrolisis adalah proses pemecahan senyawa kompleks menjadi senyawa sederhana dengan bantuan air. Proses hidrolisis pati dengan asam ditemukan pertama kali oleh Kirchoff pada tahun 1812, namun produksi secara komersial baru terlaksana pada tahun 1850. Pada proses hidrolisis sejumlah pati diasamkan sekitar $\mathrm{pH} 2$ dipanasi memakai uap di dalam suatu tangki bertekanan yang disebut konverter sampai suhu $120-140^{\circ} \mathrm{C}$. Derajat konversi yang diperoleh bergantung pada konsentrasi asam, waktu konversi, suhu dan tekanan selama reaksi. Karena hasil hidrolisis onggok berupa gula pereduksi, maka pengukuran kandungan gula pereduksi tersebut dapat dijadikan alat pengontrol kualitas. Pada hidrolisis yang sempurna, dimana pati seluruhnya dikonversikan menjadi dekstrosa. Desktrosa Ekuivalen (DE) dari larutan tersebut diberi indeks 100, dan pati yang sama sekali belum terhidrolisis memiliki DE 0 (Winarno, 2004; Anonim, 2017).

Hidrolisis dengan menggunakan asam menghasilkan pati yang strukturnya lebih renggang, sehingga air lebih mudah menguap pada waktu pengeringan. Struktur pati yang agak rapat akan lebih tinggi daya ikat airnya dan terjadi pemutusan ikatan hidrogen pada rantai linier, serta berkurangnya daerah amorf yang mudah. Suspensi pati dalam air yang dipanaskan pada suhu gelatinasi, menyebabkan pati akan dimasuki air. Suhu awal gelatinasi adalah saat terjadinya pembekuan granula pati sewaktu suhu dinaikkan. Suspensi pati dapat dihidrolisis dengan penambahan asam encer. Selama pemanasan granula pati akan mengembang dan akan terjadi penekanan antar granula, sehingga viskositas pati akan naik. Hidrolisis dihentikan setelah dicapai kekentalan yang diinginkan. Pati yang termodifikasi asam dibuat dengan mengontrol hidrolisis pati dengan asam dalam suatu suspensi. Konversi berlangsung pada suhu $50^{\circ} \mathrm{C}$ di bawah suhu gelatinasi pati dan prinsipnya adalah memotong ikatan $\alpha$-1,4-glukosida, dan $\alpha$-1,6-glukosida dari amilopektin sehingga ukuran pati menjadi lebih kecil (Winarno, 2004).

Makalah ini ditulis dengan tujuan untuk melihat sifat fisikokimia onggok dari sumber bahan baku yang berbeda (industri besar dan kecil) dan setelah dihidrolisis dengan asam sulfat, diharapkan dapat dijadikan dasar dalam melakukan pengolahan onggok menjadi produk lain.

\section{Metodologi}

\section{Bahan dan Alat}

Bahan-bahan lain yang digunakan antara lain onggok dari industri besar dan industri kecil, $\mathrm{H}_{2} \mathrm{SO}_{4}$, dan bahan kimia lain.

Alat-alat yang digunakan adalah neraca analitik, pH meter, autoklaf, oven, dan alat analisa lainnya.

\section{Metoda Penelitian}

Pelaksanaan penelitian dilakukan dalam beberapa tahap dan menggunakan sumber bahan baku yang berbeda. Perlakuan yang diterapkan pada penelitian ini adalah sumber onggok dan konsentrasi $\mathrm{H}_{2} \mathrm{SO}_{4}$. Sumber onggok berasal dari Industri Besar (A1) dan Industri Kecil/Industri Tepung Tapioka Rakyat/Ittara (A2). Konsentrasi $\mathrm{H}_{2} \mathrm{SO}_{4}$ terdiri dari 4 taraf yaitu B1 $(0,2 \mathrm{M}), \mathrm{B} 2(0,3 \mathrm{M})$, B3 $(0,4 \mathrm{M}), \mathrm{B} 4(0,5 \mathrm{M})$

\section{Pelaksanaan Penelitian}

\section{Pembuatan Tepung onggok}

Pengeringan dan penggilingan onggok untuk mendapatkan tepung anggok. Tepung onggok kemudian dianalisa, kadar air, abu, pati, serat kasar, protein, dan lemak.

\section{Proses Hidrolisa Asam.}


Hidrolisa tepung onggok dengan larutan $\mathrm{H}_{2} \mathrm{SO}_{4}$ konsentrasi $0,2 \mathrm{M}, 0,3 \mathrm{M}, 0,4 \mathrm{M}$, dan 0,5 M, menggunakan outoklaf pada suhu $121^{\circ} \mathrm{C}$ selama 30 menit tekanan $1 \mathrm{~atm}$. Hasil hidrolisa disaring. Filtrat hasil saringan dianalisa $\mathrm{pH}$ dan kadar glukosanya. Sedangkan endapannya dianalisa kadar pati dan serat kasar.

\section{Hasil Dan Pembahasan}

\section{Karakteristik Tepung Onggok}

Tepung onggok yang dipergunakan pada penelitian ini berasal dari onggok basah yang dikeringkan selama 2-3 hari, digiling kemudian di ayak, sehingga diperoleh tepung yang halus (Gambar 1).

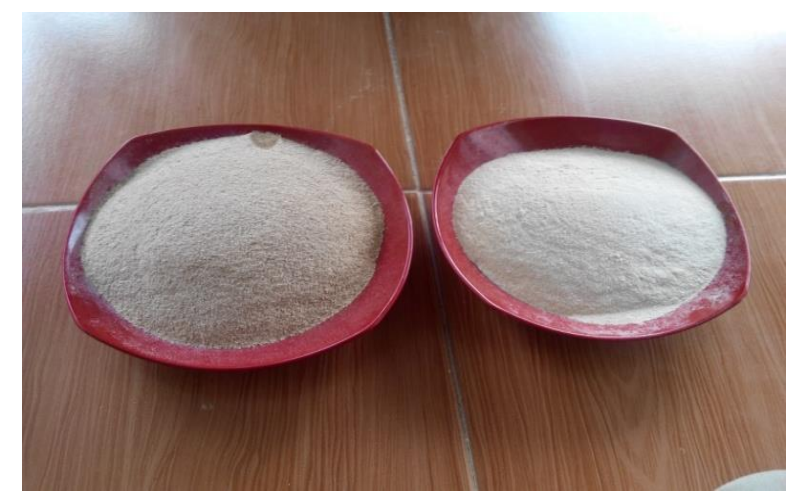

Gambar 1. Tepung onggok industri besar (kiri) dan industri kecil (kanan)

Gambar 1 memperlihatkan bentuk tepung onggok yang dihasilkan. Tepung onggok dari industri besar berwarna lebih gelap (agak coklat) dibandingkan tepung onggok dari industri kecil. Perbedaan ini diduga disebabkan beberapa hal yaitu varietas singkong dan perbedaan proses yang dilakukan untuk memperoleh tepung tapioka. Menurut Rahmaresti (2007) banyaknya onggok yang dihasilkan dipengaruhi oleh varietas singkong, umur singkong, lokasi, dan kasar halusnya parutan yang digunakan serta skala industri yang memproduksi tepung tapioka tersebut. Singkong yang digunakan industri tapioka sebagian besar berasal dari kiriman petani singkong dan sebagian lagi dari kebun perusahaan sendiri. Singkong tersebut berbeda varietasnya dan ini menyebabkan keragaman bahan baku tepung tapioka.

Berdasarkan warna daging umbi, singkong dibedakan menjadi dua macam, yaitu singkong kuning dan singkong putih. Berdasarkan rasa umbinya, singkong dibedakan menjadi dua golongan, yaitu singkong pahit dan singkong manis
(Winarno, 2004). Darjanto dan Murjati (1980) menyatakan, berdasarkan kandungan racun dalam umbi, singkong dapat dibedakan menjadi tiga golongan. Pertama yaitu golongan yang tidak beracun, dengan kadar HCN kurang dari 40 ppm (rasa tidak pahit). Yang kedua adalah golongan yang beracun sedang, dengan kadar HCN 40-100 ppm (agak pahit). Ketiga adalah golongan yang sangat beracun, mengandung HCN lebih dari 100 ppm (rasa pahit). Ada korelasi antara kadar HCN singkong segar dengan kandungan pati, yaitu semakin tinggi kadar HCN maka semakin pahit dan kadar pati meningkat dan sebaliknya. Oleh karenanya, industri tapioka umumnya menggunakan varietas berkadar HCN tinggi (varietas pahit) (BKP3 Bantul, 2012).

Produksi tepung tapioka skala rakyat banyak dikerjakan dengan alat sederhana. Pada beberapa tahap proses masih digunakan tenaga manusia. Karakteristik industri tersebut adalah modal relatif kecil, biaya perawatan relatif tinggi, teknologi yang digunakan umumnya sederhana, dan kualitas produk umumnya rendah (Damardjati, 1995).

Sedangkan pada proses secara industri atau secara teknologi yang pada dasarnya sama namun berbeda dalam penggunaan peralatan dan bahan lainnya. Prosesnya meliputi proses pembersihan (dilakukan dalam 3 tahap dengan bak cucian berbeda). Proses penggilingan. Pada tahap ini ada 2 proses yaitu pencacahan dan pemarutan. Proses pemisahan. Di tahap ini ada 3 proses yaitu pertama adalah proses di mesin ekstraktor yaitu memeras bubur singkong diambil airnya kemudian ampasnya di buang. Proses yang kedua adalah proses pemisahan air tapioka dengan air getah singkong menggunakan mesin sparator setrifugal sehingga cairan menjadi kental. Proses yang ketiga ialah pemisahan tapioka dengan air menggunakan mesin peras atau biasa orang pabrik menyebutnya senterfius. Selanjutnya proses pengeringan, yang menggunakan udara panas. Terakhir proses pengepakan. Pada proses ini tapioka dibungkus berdasarkan kebutuhan biasanya dipak dengan berat $25 \mathrm{~kg}$ dan $50 \mathrm{~kg}$. Pada proses pembuatan tapioka secara industri, hasil rendemen terbaik biasanya 25 persen (Direktorat Pengolahan Pangan Hasil Pertanian, 2005; Anonim, 2005). Selain itu pada industri besar juga menggunakan gas sulfur untuk menghasilkan tepung yang lebih putih.

Adanya perbedaan proses dan peralatan yang digunakan menyebabkan onggok yang dihasilkan juga berbeda. Pada industri kecil, produksi yang 
tidak besar membantu penanganan onggok lebih baik dibandingkan pada industri besar. Pada beberapa industri tapioka skala kecil di Lampung yang sudah menerapkan proses produksi yang terkendali (seperti pada industri tempat pengambilan sampel penelitian ini) mampu menghasilkan tepung onggok yang bermutu yang banyak diminati industri saus sambal.

Karakteristik tepung onggok dapat dilakukan dengan menganalisa kandungan tepung onggok melalui uji proksimat. Analisis proksimat adalah suatu metode analisi kimia untuk mengidentifikasi kandungan nutrisi suatu bahan seperti protein, lemak, karbohidrat. Analisis ini bermanfaat sebagai penilaian kualitas bahan terutama pada standar zat makanan yang terkandung di dalamnya. Hasil analisis tepung onggok dapat dilihat pada Tabel 1.

Tabel 1. Kadar proksimat tepung onggok

\begin{tabular}{lcc}
\hline \multicolumn{1}{c}{ Parameter } & $\begin{array}{c}\text { Industri } \\
\text { Besar } \\
\text { (rerata) }\end{array}$ & $\begin{array}{c}\text { Industri } \\
\text { Kecil } \\
\text { (rerata) }\end{array}$ \\
\hline Kadar air (\%) & 4,17 & 6,86 \\
Kadar abu (\%) & 1,93 & 1,95 \\
Kadar protein & 1,04 & 1,42 \\
$\begin{array}{l}\text { (\%) } \\
\text { Kadar lemak (\%) }\end{array}$ & 0,11 & 0,17 \\
Kadar pati (\%) & 40,8 & 46,5 \\
$\begin{array}{l}\text { Kadar serat kasar } \\
\text { (\%) }\end{array}$ & 23,93 & 14,08 \\
\hline
\end{tabular}

Tabel 1 menunjukkan bahwa kadar proksimat tepung onggok industri besar dan Ittara tidak jauh berbeda khususnya untuk kadar air, abu, protein dan lemak. Namun untuk kadar pati dan serat kasar agak berbeda diantar keduanya. Onggok dari industri besar (disimbolkan PT) mengandung kadar pati lebih rendah dan serat kasar lebih tinggi dibandingkan onggok dari industri kecil (disimbolkan Ittara/Industri Tepung Tapiok Rakyat). Kondisi ini disebabkan proses produksi tepung tapioka pada industri besar lebih efisien dengan mesin yang baik. Proses produksi tepung tapioka pada Ittara kurang efisien karena mesin yang digunakan, sehinggasisa pati pada onggok masih lebih besar dibandingkan onggok industri besar.

Komponen utama pada tepung onggok adalah pati. Pati yang dihidrolisis akan berubah menjadi gula. Semakin banyak pati yang terhidrolisis maka akan semakin banyak kadar gula yang diperoleh untuk selanjutnya menjadi sumber makanan dalam proses fermentasi. Sehingga bila proses ini akan diteruskan melalui bantuan mikroba fermentatif diharapkan akan menghasilkan bioetanol. Banyaknya gula akan mempengaruhi kadar etanol yang dihasilkan.

Pada onggok terdapat juga terdapat serat kasar. lemak, protein, kadar abu, dan kadar air. Menurut Widayatnim (2015) serat kasar terdiri atas selulosa dan hemiselulosa yang sifatnya sulit terhidrolisis, sehingga jika semakin banyak kandungan serat kasar maka mempengaruhi kadar gula yang diperoleh lebih sedikit. Begitu juga dengan kadar lemak. Menurut Anna dkk. (2005) lemak yang terhidrolisis akan berubah menjadi asam lemak dan gliserol, bukan gula, sehingga kandungan lemak yang tinggi akan mempengaruhi kadar gula yang diperoleh menjadi lebih sedikit. Namun lain halnya dengan kandungan protein. Menurut Slamet (1989) protein yang terhidrolisis akan melepas asam-asam amino penyusunnya. Asam amino yang sesuai bagi enzim dapat berfungsi sebagai energi enzim untuk bekerja, diantaranya enzim amilase yang bekerja merombak pati menjadi gula. Meskipun hasil hidrolisis protein bukan berupa gula, namun dengan protein yang banyak terhidrolisis maka energi bagi enzim bekerja juga semakin banyak, sehingga enzim dapat bekerja maksimal sesuai tugasnya.

abu merupakan zat organik sisa hasil pembakaran bahan organik yang erat kaitannya dengan mineral bahan berupa garam organik dan anorganik, sehingga abu memiliki sifat konduktivitas (kemampuan menghantarkan panas). Artinya, meskipun abu tidak dapat dijadikan bahan yang dapat dirombak menjadi etanol, namun dengan sifat konduktivitasnya tersebut, abu dapat membantu mempercepat proses pemasakan tepung onggok menjadi bubur, serta proses hidrolisis untuk membantu memecah rantai kompleks karbohidrat menjadi monomer yang lebih sederhana (Slamet, 1989).

\section{Proses Hidrolisa $\mathrm{H}_{2} \mathrm{SO}_{4}$}

Proses hidrolisa biasanya digunakan untuk membantu pemecahan bahan menjadi komponen yang lebih sederhana dan mudah digunakan untuk tahap selanjutnya seperti proses fermentasi, didahului dengan proses hidrolisa asam selama 30 menit pada suhu $121^{\circ} \mathrm{C}$ tekanan 1 atm dengan autoklaf. Pada penelitian ini menggunakan asam sulfat $\left(\mathrm{H}_{2} \mathrm{SO}_{4}\right)$ dengankonsentrasi $0,2 \mathrm{M}, 0,3 \mathrm{M}, 0,4 \mathrm{M}$, dan 0,5 M. Hasil hidrolisa kemudian diamati $\mathrm{pH}$, 
kadar gula reduksi $(\mathrm{mg} / \mathrm{ml})$, dan pati (\%) seperti tertera pada Tabel 2 .

Tabel 2. Hasil analisa onggok setelah dihidrolisa dengan $\mathrm{H}_{2} \mathrm{SO}_{4}$

\begin{tabular}{lllll}
\hline $\mathrm{H}_{2} \mathrm{SO}_{4}$ & \multicolumn{2}{c}{ Gula Reduksi (mg/ml) } & $\mathrm{pH}$ & \\
\cline { 2 - 5 } & $\begin{array}{c}\text { Industri } \\
\text { kecil }\end{array}$ & $\begin{array}{c}\text { Industri } \\
\text { besar }\end{array}$ & $\begin{array}{c}\text { Industri } \\
\text { kecil }\end{array}$ & $\begin{array}{r}\text { In } \\
\text { b }\end{array}$ \\
\hline $0,2 \mathrm{M}$ & 3.32 & 1.86 & 1.79 \\
$0,3 \mathrm{M}$ & 3.64 & 1.94 & 1.86 \\
$0,4 \mathrm{M}$ & 3.89 & 2.47 & 2.59 \\
$0,5 \mathrm{M}$ & 1.63 & 1.43 & 2.42 & \\
\hline
\end{tabular}

Tabel 2 menunjukkan kadar gula reduksi, $\mathrm{pH}$, dan pati onggok masing-masing konsentrasi $\mathrm{H}_{2} \mathrm{SO}_{4}$. Pada keseluruhan proses hidrolisa ini kadar gula reduksi tertinggi yaitu $3,89 \mathrm{mg} / \mathrm{ml}$ (industri kecil) dan $2,47 \mathrm{mg} / \mathrm{ml}$ (industri besar) yang berasal dari penggunaan $\mathrm{H}_{2} \mathrm{SO}_{4}$ sebesar 0,4 M. Penggunaan $\mathrm{H}_{2} \mathrm{SO}_{4}$ 0,4 M menghasilkan glukosa paling tinggi dibandingkan konsentrasi lainnya. Jumlah $\mathrm{H}_{2} \mathrm{O}$ dalam larutan $\mathrm{H}_{2} \mathrm{SO}_{4}$ 0,2 $\mathrm{M}$ dan 0,3 M lebih banyak dari konsentrasi $0,4 \mathrm{M}$ sehingga berpengaruh terhadap viskositas larutan yang dihidrolisa. Semakin besar viskositas larutan, tumbukan antar reaktan menjadi berkurang sehingga reaksi berjalan lebih lambat. Hal ini disebabkan $\mathrm{H}_{2} \mathrm{SO}_{4}$ berfungsi sebagai katalis, sehingga semakin besar konsentrasi katalis maka semakin cepat pula reaksi berlangsung yang akan menghasilkan kadar glukosa yang besar. Katalis berguna untuk mempercepat jalannya reaksi hidrolisa dimana yang berpengaruh terhadap kecepatan reaksi adalah ion H-nya (Anonim, 2018)

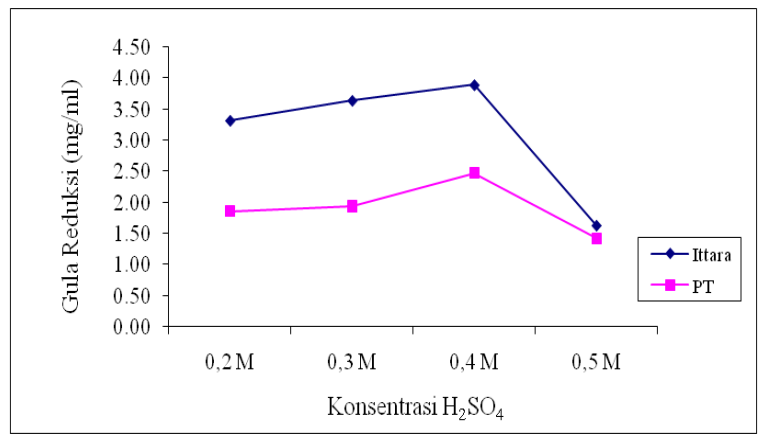

Gambar 2. Kurva perubahan kadar gula reduksi onggok hasil hidrolisa pada berbagai konsentrasi $\mathrm{H}_{2} \mathrm{SO}_{4}$
Gambar 2 menunjukkan kadar gula reduksi terbanyak hasil hidrolisa dicapai pada saat konsentrasi larutan 0,4 M. Dalam proses hidrolisa gugus $\mathrm{H}^{+}$dari asam akan mengubah gugus serat dari onggok menjadi gugus radikal bebas. Gugus radikal bebas serat yang dxiriffoblian akan berikatan dengan Indgusglis $\mathrm{OHIndlaritair} \mathrm{dannblareaksi}$ pada suhu $120^{\circ} \mathrm{C}$ bernghasilknecgula redubsiarpada saat konsentrasi

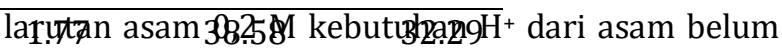
me.gøukupi sejbingga tidak2bagsak terbentuk gugus radiblal bebas danj onggol 3dan gula reduksi yang

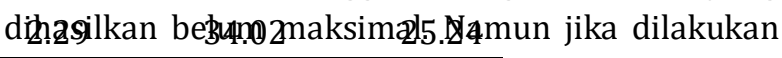
penambahan konsentrasi larutan asam terlalu banyak $(0,5 \mathrm{M})$ justru gula reduksi yang dihasilkan semakin menurun. Penambahan konsentrasi larutan asam akan terbentuk lebih banyak gugus radikal bebas, tetapi penambahan konsentrasi larutan asam menyebabkan semakin sedikit air dalam komposisi larutan hidrolisa. Sehingga kebutuhan $\mathrm{OH}^{-}$sebagai pengikat radikal bebas serat berkurang dan glukosa yang dihasilkan semakin sedikit (Lavarack et al., 2002) Dengan demikian konsentrasi asam yang paling optimum saat reaksi hidrolisa untuk menghidrolisa onggok menjadi gula reduksi yang terbanyak adalah $0,4 \mathrm{M}$.

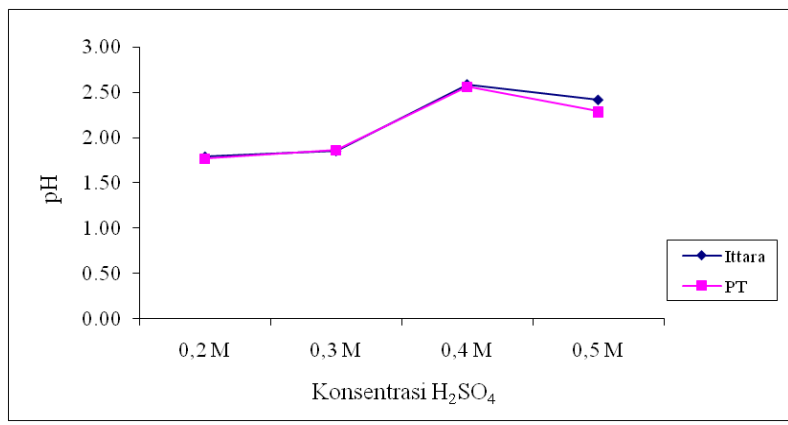

Gambar 3. Kurva perubahan $\mathrm{pH}$ onggok hasil hidrolisa pada berbagai konsentrasi $\mathrm{H}_{2} \mathrm{SO}_{4}$

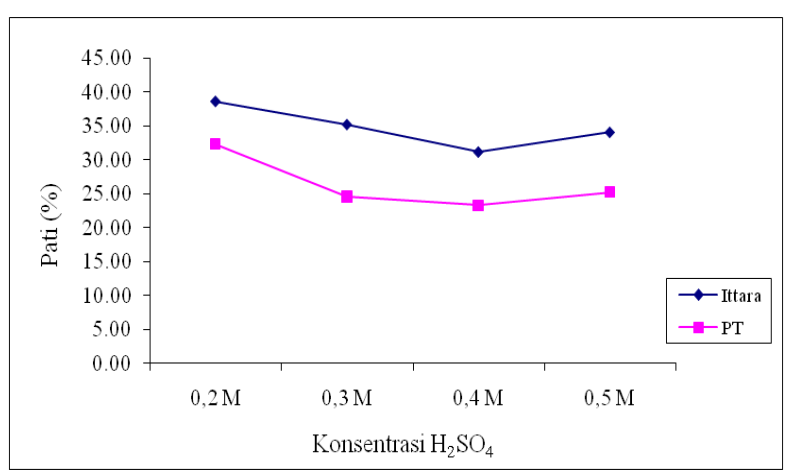

Gambar 4. Kurva perubahan kadar pati onggok hasil hidrolisa pada berbagai konsentrasi $\mathrm{H}_{2} \mathrm{SO}_{4}$ 
Gambar 3 dan 4 menunjukkan perubahan kadar gula reduksi dan $\mathrm{pH}$ onggok dengan bertambahnya konsentrasi $\mathrm{H}_{2} \mathrm{SO}_{4}$. Bentuk perubahan tersebut berbanding terbalik dengan perubahan kadar pati onggok hasil hidrolisa (Gambar 4). Gambar 2 sampai dengan 4 juga menunjukkan perbedaan kadar gula reduksi, pati, dan pH karena perbedaan sumber onggok. Onggok dari industri kecil menghasilkan gula reduksi yang lebih tinggi dibandingkan onggok dari industri besar.

\section{Kesimpulan}

Tepung onggok dari industri besar mengandung kadar air, abu, lemak, protein dan pati lebih rendah, namun lebih tinggi kadar serat kasar dibandingkan tepung onggok industri kecil. Konsentrasi asam sulfat yang optimum untuk menghidrolisis onggok industri kecil dan industri besar pada konsentrasi 0,4 M selama 30 menit pada suhu $121^{\circ} \mathrm{C}$, menghasilkan gula reduksi sebesar 3,89 $\mathrm{mg} / \mathrm{ml}$ (industri kecil) dan 2,47 mg/ml (industri besar).

\section{Daftar Pustaka}

Amalia S. 2012. Pengaruh level penggunaan cassabio dalam konsentrat terhadap fermeabilitas dan kecernaan ransum ruminansia (In Vitro) [Skripsi]. Bogor (ID): Institut Pertanian Bogor

Anna, P., Titin, S., dan P. Soemodimedjo. 2005. DasarDasar Biokimia. Universitas Indonesia. Jakarta. 469 hal.

Anonim. 2005. Proses Pembuatan Tapioka di Pabrik. ssidiqiu.blogspot.com/.../proses-pembuatantapioka-di-pabrik.html. [21 Juni 2018]

Anonim. 2017.

Hidrolisis. https://id.wikipedia.org/wiki/Hidrolisis. [21 Juni 2018].

Anonim. 2018. Laju reaksi. https://id.wikipedia.org/wiki/Laju_reaksi. [21 Juni 2018].

BKP3 Bantul. 2012. Cara pembuatan tepung MOCAF. bkppp.bantulkab.go.id/documents/2012110 5140749-MOCAF.pdf. diakses tanggal 17 april 2016.

Damardjati, D.S. 1995. Food Processing in Indonesia: the Development of SmallScale Industri. Bogor Research Institute for Food Crops Biotechnology Agency for Agricultural Research and Development, Bogor. $13 \mathrm{hlm}$

Darjanto dan Murjati. 1980. Khasiat, Racun dan Masakan Ketela Pohon. Bogor: Yayasan Dewi Sri
Direktorat Pengolahan Pangan Hasil Pertanian. 2005. Pengembangan Usaha Pengolahan Tepung Tapioka. Departemen Pertanian, Jakarta.

Lavarack, B.P., G.J. Griffin, D. Rodman. 2002. Measured kinetics of acid-catalysed hydrolysis of sugar cane bagasse to produce xylose, Catalysis Today, 63: 257 - 265.

Puspitasari, R.P. 2009. Pembuatan Etanol dari Nira Sorgum dengan Proses Fermentasi. Skripsi Sarjana Jurusan Teknik Kimia. Universitas Diponegoro, Semarang.

Rahmarestia, E. 2007. Onggok Terfermentasi dan Pemanfaatannya. (Skripsi). FMIPA Uiversitas Negeri Yogyakarta. Yogyakarta.

Slamet, S. 1989. Analisis Bahan Makanan dan Pertanian. Liberty. Yogyakarta.

Widayatnim. 2015. Bioetanol. Digilib.itb.ac.id. [23 Juni 2016]

Winarno, FG. 2004. Kimia Pangan dan Gizi. Jakarta : Gramedia 